\title{
Effects and Action Mechanism of Low Level Laser Therapy (LLLT): Applications in Periodontology
}

\author{
loannis K Karoussis ${ }^{1 *}$, Kyriaki Kyriakidou ${ }^{1}$, Costas Psarros ${ }^{1}$, Michael Koutsilieris ${ }^{2}$ and John A Vrotsos ${ }^{1}$ \\ ${ }^{1}$ Department of Periodontology, National and Kapodistrian University of Athens, School of Dentistry, Athens, Greece \\ ${ }^{2}$ Department of Experimental Physiology, Medical School, National and Kapodistrian University of Athens, Greece
}

*Corresponding author: Ioannis K Karoussis, Department of Periodontology, National and Kapodistrian University of Athens, School of Dentistry, Athens, Greece, Mikras Asias 75 Goudi, 15773, Athens, Greece, Tel: +302107461314; E-mail: ikaroussis@dent.uoa.gr

Received date: September 17, 2018; Accepted date: September 20, 2018; Published date: September 25, 2018

Copyright: (c) 2018 Karoussis IK, et al. This is an open-access article distributed under the terms of the Creative Commons Attribution License, which permits unrestricted use, distribution, and reproduction in any medium, provided the original author and source are credited.

\begin{abstract}
Lasers nowadays have several applications in many research fields. In the life sciences and especially in Periodontology, Low Level Laser Therapy (LLLT) has proven to be particularly interesting. Low intensity radiation in specific wavelengths has been known to trigger cellular proliferation and differentiation, through molecular mechanisms that are still not fully elucidated. These effects might be triggered by mitochondria and through Reactive Oxygen Species (ROS). These in turn, can activate other molecular pathways and signaling cascade, resulting in the activation of a plethora of transcriptional factors. In this review we aim to highlight the mechanism of action and the effects of LLLT. We also aim to highlight how different wavelengths and energy applied can have a distinct impact on the effectiveness of LLLT. Finally, we provide insight on its current and potential future applications.
\end{abstract}

Keywords: Cells; Growth factors; Lasers; Mitochondria

Abbreviations: LLLT: Low Level Laser Therapy; NO: Nitric Oxide; COX: Cytochrome C Oxidase; ROS: Reactive Oxygen Species; ATP: Adenosine Triphosphate; AP-1: Activator Protein 1; GF: Growth Factor; PDGF: Platelet-Derived Growth Factor; TGF- $\beta$ : Transforming Growth Factor Beta; FGF: Fibroblast Growth Factor; IGF: Insulin-like Growth Factor; BMP: Bone Morphogenetic Protein; PGE2: Prostaglandin E2; IL-1b: Interleukin-1b; IFN- $\gamma$ : Interferon gamma; Nd-YAG: Neodymium-doped Yttrium Aluminium Garnet; KTP: Potassium Titanyl Phosphate; COX-2: Cyclooxygenase-2; MAPK: Mitogen Activated Protein Kinase

\section{Introduction}

Nowadays, Lasers have a multitude of applications, ranging from mechanical to life sciences. In the field of Periodontology, Lasers are mostly known for their application in the removal of tissues or hemostasis through their ability to enhance the cellular processes throughout the applied energy in terms of space, time, and surface. The provision of large quantities of energy per unit area (High Level Laser Therapy or HLLT), can cause photothermal or photomechanical phenomena which are utilized when laser radiation is used for the removal of hard or soft tissues. Another important laser application is the low-power treatment, better known as LLLT. This process has been described as Soft Laser Therapy or Low Intensity Laser Therapy. It relies on the ability of light to function as a photo-stimulant in living cells by exerting its effects through photoelectric, photo-physical and photochemical phenomena. Despite significant research efforts around the effects of LLLT in various cells or tissues, the appropriate doses of radiation, energy densities, time, and irradiation conditions as well as the appropriate individual settings in the various laser devices, which will predictably lead to optimal therapeutic effects, have not been clarified yet. However, the existence of several laser types of many different parameters to be selected as referred above, seem rather confusing to the reader and the researcher, without providing a clarified view. What is generally accepted is that the energy density required is very small, at the level of $2-4 \mathrm{~J} / \mathrm{cm}^{2}$ and the transmit power is less than 0.5 Watts.

It appears that the bio-stimulatory activity in tissues relates to short wavelengths, since the best results are displayed in red and nearinfrared light spectrum. It is striking that, as per several descriptions, LLLT application has even achieved restoration of neural tissue injuries of the spine [1]. It is also highly interesting that studies have proved the beneficial effects of LLLT in the healing of peripheral nerve injuries and the regeneration of neuro-axons of injured nerves in animal models [2,3], as well as iatrogenic numbness improvement of the inferior alveolar nerve in humans [4].

\section{Action Mechanism of LLLT}

The photobiological-photochemical phenomena caused by laser radiation to the tissues, are similar to photosynthesis carried out by plants. To enable the visible light of low energy to affect any living biological system, the energy-carrying photons must be absorbed by electrons belonging to a photoreceptor or chromophore of the target biological system [5]. It has been theorized that the radiation red or near-infrared spectrum, causes stimulation of mitochondria [6]. The photoreceptor molecules or widely known as chromophores are molecules or portions of molecules which confer a particular color to the molecule or substance to which they belong. The chromophores are either conjugated electron transport systems or metal complexes. Characteristic examples of chromophores are observed in chlorophyll, hemoglobin, Cytochrome Oxidase C (COX), myoglobin, flavoproteins and porphyrins [7]. The photoreceptor molecules of mitochondria, on which laser radiation seems to act as a photo-stimulant, can trigger a series of photo-chemical reactions, which in turn, can cause changes in cellular metabolism, such as protein signaling. The key photoreceptor 
Page 2 of 6

molecule is COX, the last enzyme in the electron transport chain of mitochondria. Those photoreceptor molecules are NADPH oxidase, Nitric Oxide (NO), cytochrome aaCytochrome aa3 quinol oxidase, subunit III (respiratory chain component) while the key photoreceptor is the molecule of $\operatorname{COX}$ (a key molecule of the mitochondrial respiratory chain) (Figure 1) [8]. NO which is generated in the mitochondria of the cells when they are under stress or oxygen deficiency conditions, interferes with respiration because it antagonizes the oxygen in connection with COX [9]. It is described that LLLT application in cell cultures or in experimental models, results in an increase of NO concentration. This is because laser radiation causes release of NO by mitochondria and COX [10]. The result is the lifting of the respiratory interference that had caused the connection of NO with COX, because the flow of oxygen is restored, so that once respiration has re-started, ROS are produced [11].

The oxygen radicals (singlet oxygen molecules) (ROS), as free radicals play an important role in the formation of Adenosine Triphosphate (ATP), which in turn is the energy storage of the cell [12]. LLLT results in respiratory re-start through the release of NO by iron ions and copper COX, oxygen recapture, production of ROS and ATP production increase. It should be noted that the release of NO under the influence of low-power laser radiation, is affected by other cell energy storages such as hemoglobin and myoglobin molecules which capture NO [13].

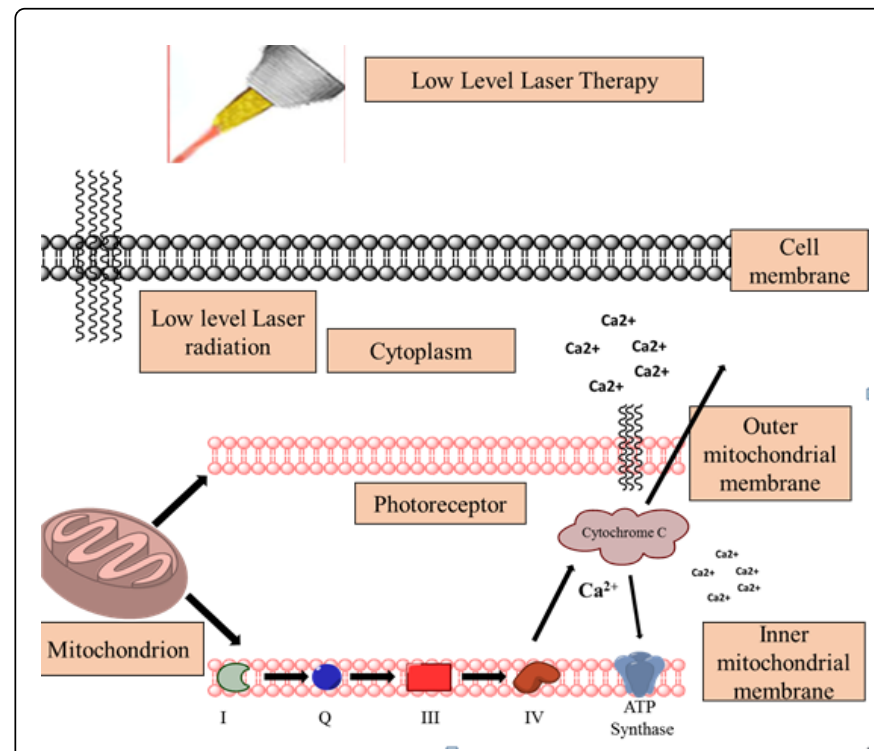

Figure 1: Schematic diagram illustrating the absorption of laser light by chromophores and photoreceptors identified in the mitochondrial respiratory chain. Respiratory chain in mitochondria: Through a series of chemical reactions of molecules such as NADH and Cyt, the final product is ATP.

Furthermore, LLLT, induces the synthesis of transcription factors. This phenomenon is regulated by increasing ROS production, which causes increased production of hydroperoxide anion and finally increased concentration of $\mathrm{H}_{2} \mathrm{O}_{2}$ [14-16]. In turn, the above changes influence transcription factors the most important of the nuclear factor $\mathrm{kB}(\mathrm{NF}-\mathrm{kB})$ and Activator protein 1 (AP-1) (Figure 2). That is, the free radicals are not only involved in the intracellular signaling procedure but also promote the nucleic acid synthesis in the nucleus, the formation of proteins, the activation of enzymes and the cell cycle promotion [17]. Finally, LLLT causes change in the biochemical cell activity due to the transient heating of the chromophore molecules. This happens with the small dose of energy, minimally supplied, if there is no increase in tissue temperature [17] (a slight increase of $1^{\circ} \mathrm{C}$ is attributed to the activation of cellular metabolism).



Figure 2: One of the potential laser action mechanisms in tissues, wherein the red and near-infrared range radiation photons are absorbed by mitochondria, which generate ROS and release NO, which in turn leads to the transcription of specific genes through the activation of transcription factors such as NF-kB and AP-1.

As it has been clarified, the primary reactions taking place in the mitochondria are followed by a series of chain reactions that occur in the cell resulting in the modification of cellular homeostasis. So, change is observed in the $\mathrm{pH}$, in the concentration of intracellular $\mathrm{Ca}^{2+}$ [11], in the ATP and the cAMP as well as in the redox potential. The mechanisms described above, which have been proposed as a possible explanation of the effect of radiation on tissues, are quite complicated. These changes at the cellular level have been hypothesized to explain the clinical observation of a series of positive effects of LLLT, such as increased cell proliferation, accelerating the healing process, promoting tissue regeneration, preventing cell death, analgesic action, relieve of neurogenic pain (laser acupuncture), anti-inflammatory activity etc. The synthesis of DNA and RNA and the increase of cell proliferation is induced by the increase of the intracellular $\mathrm{Ca}^{2+}$ concentration provoked by LLLT activity on the $\mathrm{Ca}^{2+}$ channels [18].

Despite what has been said above regarding the mechanisms by which LLLT exerts its bio-stimulatory action, the exact mechanism that causes analgesia has not been identified. It has been argued that the laser light selectively stimulates the free nerve endings, which are located in the superficial layers of the skin and mucous membranes. Their effect is based on mechano-thermal phenomena which in some way affect the nociceptive afferent nerve fibers $[19,20]$, changing their activity and suppressing neurostimulators resulting from the pain receptors of peripheral nerves [21]. The analgesic effect of LLLT however, has been supported by systematic reviews of both medical $[22,23]$ and dental fields [24].

A special mention is worth to the effectiveness of LLLT in the treatment of dentinal hypersensitivity. A success in pain relief reaching the percentage of $90 \%$ has been reported. This interesting effect is 
probably exerted through inhibition of the depolarization of $\mathrm{C}$ pulp fibers $[25,26]$.

Low doses of energy induce all these favorable effects. When high doses of energy are administered at the same wavelength, the results are least favorable or even catastrophic for the cell. This is called biphasic response to the radiation dose [17]. The larger power supply, however (e.g., by increasing the time of exposure, or the energy density), will lead to warming, depletion of mitochondrial respiratory chain and ultimately cell death. Providing even more energy by increasing the intensity, reducing the pulse time, and increasing the frequency in the device, would lead to photocoagulation and photosublimation of the irradiated tissue $[18,27,28]$. In applying radiation of low energy density, it has been clearly shown that very good therapeutic effects in tissues that were damaged are achieved (cells not operating normally). In contrast, when applied on healthy cells, or tissues in which inflammation was artificially induced, LLLT did not bring such good results $[29,30]$.

\section{Low Level Laser Therapy (LLLT) and Healing of Tissues}

During the healing process, there is a series of well-orchestrated and controlled events with which the body is trying to achieve regeneration of damaged by a traumatic or infectious cause tissue, both morphologically and functionally. Healing begins with inflammation that is created after the injury or the exercise of another damaging cause. Initially, various types of cells are chemotactically attracted to the injured area and phagocytize tissue remnants, bacteria, and impurities. Subsequently, new extracellular matrix is created, which functions as a scaffold for cell built up, creating vascular neoplasms, and finally bridging and reuniting the trauma edges. The complete healing is achieved with the maturation of the newly formed tissue. If the newly formed tissue is identical structurally and functionally with the background, regeneration of tissue has been successfully achieved. If the new tissue is not structurally or functionally identical to its predecessor, then we are talking about reparation [31]. Healing performed after a trauma or other cause, is not the same in all cases. It differs per type of cause, extent of damage, type of affected tissue etc.

After the effect of a damaging cause (trauma, surgery, infection, burn, etc.) and the creation of damage which extends beneath the epithelium to the underlying connective tissue, the result is injury to the blood vessel which subsequently causes fibrin formation and platelet thrombus. Then the activation of various cells begins within the trauma and into the adjacent tissue [31]. The sequence of the wellorchestrated events that follow, such as chemotaxis, proliferation, cell differentiation, and the composition of the intercellular matrix, is controlled and regulated by biological mediators, called Growth Factors (GFs). These are molecules of polypeptide nature, whose influence on the tissue healing are similar for all types of tissues, including the periodontal one [32].

The main GFs involved in the healing process are: The PlateletDerived Growth Factor (PDGF), the Transforming Growth Factor Beta (TGF- $\beta)$, the acidic and basic Fibroblast Growth Factor ( $(\mathrm{aFGF})$ and (bFGF) respectively), the Insulin-Like Growth Factors (IGF-I and -II) and the Bone Morphogenetic Proteins (BMPs).

Cells such as platelets, fibroblasts, vascular endothelial cells, and immune cells, play a key role in the healing process. Through a complex sequence of events, chemotaxis, proliferation, and differentiation of cells finally results in tissue healing. A few years after the laboratory preparation of laser beam, the scientists tried to take advantage of the ability of the radiation effect on living matter and investigate the relationship between LLLT and trauma healing [33]. First, the Hungarian physician, Endre Mester from Semmelweis University, used the term bio-stimulation and studied the effect of LLLT laser-rubidium on animals. After the use of radiation on mice, which had been shaved on the back and then irradiated with low intensity radiation, it was found firstly that the mice did not develop tumor lesions and, secondly, that the flanks of the mice in the irradiation group grew faster compared to the group not irradiated [34].

Since then, numerous studies on a cellular level, laboratory animals, and in humans have confirmed the beneficial effect of laser treatment on wound healing. It has been argued that the best time to apply LLLT is at the stage of cell proliferation $[35,36]$. It has been shown that LLLT can cause increased bFGF production, which exerts mitogenic activity and induces angiogenesis and tissue repair [37,38]. Furthermore, after applying LLLT an increase of cell proliferation of gingival fibroblasts and bFGF and IGF-1 release [39], have been demonstrated as well as increased protein levels and the corresponding mRNA of biological ILIa mediators and IL-8 [40]. In other studies, an increase of the secretion of VEGF, bFGF, HGF and SCF GFs was found, which also promotes the proliferation of fibroblasts [41]. Increased production of Prostaglandin E2 (PGE2) through the introduction of Cyclooxygenase-2 (COX-2) mRNA has also been described $[42,43]$. The effect of PGE2 in the periodontal tissue cells is dose-dependent and at low concentrations it appears to contribute to the reformation. In international literature, there is a plethora of research data that support the positive effect of LLLT on cell proliferation $[39,43,44]$. Besides the increase in cell proliferation, it has been argued that LLLT may promote cell differentiation as well. For example, transformation of fibroblasts into myofibroblasts has been found [45].

However, far fewer investigations have focused on identifying the intensity of the provided radiation as well as the energy density which would safely and predictably result in the bio-stimulation of cells rather than in their destruction [46,47]. Perhaps the heterogeneity between different conditions and irradiation methods used in different surveys is the reason for which other researches have produced opposite views - that is, that LLLT application offers no benefit to the healing process. For example, some researchers have failed to achieve a statistically significant difference in healing time, in animals or humans [48-50].

This was the result of a systematic review of the available studies on the effect of LLLT in the treatment of osteoarthritis. It was concluded that well-organized studies with the corresponding laser and irradiation conditions, from which firm conclusions could be drawn on the role and therapeutic doses of LLLT, were absent [51]. The different results between 'similar' studies can be attributed to irradiation with inadequate or, on the contrary, excess energy, to the use of incorrect frequency on irradiation of inadequate or incorrect affected area etc. [52]. In another systematic review of the in vitro studies and the studies on animals concerning LLLT, the authors concluded that the data from studies on animals are insufficient to generalized conclusions as to the reliability of the therapeutic approach in humans [53]. Even though, there is a lot of research data and a number of systematic reviews [54], which successfully demonstrate the beneficial effect of LLLT on trauma healing [55], at reducing pain [56], in strengthening neo-angiogenesis [56], in healing vesicular stomatitis lesions [57], in treating mucositis of irradiated patients at the oropharyngeal region [58], etc., further, well-designed surveys are 
required to clarify the whole thing, especially the doses and conditions of irradiation [59].

In periodontal literature, several studies are reported on the effect of LLLT on fibroblasts of the connective tissue [60], to the periodontal ligament cells [61] and osteoblasts of the alveolar and jaw bones [62].

Enough evidence supports the beneficial effects of laser radiation on the proliferation and activation of fibroblasts. Also, a dose-dependent reduction in the production of PGE2, by decreasing the expression of COX-2 has been argued [63]. Moreover, it has been demonstrated that LLLT affects, in a dose dependent manner, on gingival fibroblasts, preventing the production of Interleukin-1b (IL-1b) [64]. The very fact that LLLT has provided a decrease in the expression of cytokines IL-1b and Interferon gamma (IFN- $\gamma$ ), as well as an increase in the expression of GFs (PDGF, TGF-b, bFGF), leads to the interesting conclusion that lasers exert anti-inflammatory activity and promote healing [64]. The positive effect on healing has been demonstrated through an in vitro study of LLLT effect (with KTP or Nd-YAG Laser) on a primary culture of skin fibroblasts, in which increased collagen production, increased secretion of antioxidant enzymes and increased vinculin expression appeared (adhesion molecules expressed by endothelial cells $[65,66]$. The LLLT with diode laser also has a positive effect in the healing of the gingiva, showing to lead to increased mRNA production of GFs VEGF and TGF- $\beta$ and collagen type 1 [67].

The knowledge about the success of the reconstructive procedure with the application of LLLT, gave thought to its application to promote regeneration of damaged periodontal tissues. It has been supported that the ability of LLLT to suppresses the plasminogen activator production of COX-2, phospholipase A2 (enzymes responsible to produce PGE2), PGE2, IL-1b, prevents the degradation of the extracellular matrix since it reduces collagen destruction that occurs when the cells are found under stress conditions [68]. Furthermore, the beneficial effect of LLLT on the proliferation of periodontal ligament cells has been strongly supported [69-71], whereas other investigators have questioned it [46]. Interesting is a study which evaluated the possible additional effect of LLLT in the implementation of protein matrix of the enamel (Emdogain ${ }^{\circ}$ ), in endosteal injuries which were caused by periodontitis in humans. Although there was no statistically significant difference in the adhesion increase and the reduction of the depth of the follicles, significantly less recession was observed in patients treated with LLLT [72].

However, LLLT has also bio-stimulatory activity in cells of the bone tissue. It has been demonstrated that LLLT with Nd:YAG laser causes an increase in cell proliferation in cultured cell lines of osteoblasts [73]. In relatively recent experimental study on rats, Altan, et al. [74] demonstrated that LLLT causes acceleration of bone remodeling during orthodontic tooth movement, promoting the proliferation and function of osteoblasts and osteoclasts. The increase in cell proliferation was confirmed by studying the LLLT effect with Nd: laser YAG both in primary osteoblast cultures and in osteoblast cell line [62]. For the explanation of the phenomenon, activation of the Mitogen Activated Protein Kinase (MAPK) [62], increase of the BMP-2 expression of osteocalcin and TGF-b1 have been investigated and demonstrated [75]. Indeed, it has been shown that favorable results are obtained with the smallest possible doses [73].

Moreover, molecular techniques have confirmed the effect of LLLT and the diversification of pre-osteoblasts [76]. In studies regarding therapeutic intervention to treat intraosseous periodontal defects in humans, it was estimated that the effect of LLLT combined with alloplastic graft, with clinical and radiographic criteria in the first 3 postoperative months, was positive. However, after six months there was no difference with the control group. So, it was concluded that the LLLT worked in accelerating the healing process $[77,78]$. Indeed, it was found in vitro, that the LLLT increases alkaline phosphatase activity and mRNA expression of substances such as osteocalcin, bone sialoprotein and osteopontin, which are all indicators of osteoblastic differentiation [78].

In the field of implantology, animal studies suggested that LLLT with diode laser application on the bone of the recipient position has resulted in faster osseointegration and higher percentage of bone to implant contact. Moreover, it appeared that the torques required to export osseointegrated implants and the percentages of calcium and phosphorus (ratio by weight) in peri-implant bone were statistically higher in the group of animals that received LLLT. It was concluded that increased levels of calcium and phosphorus demonstrate faster bone maturation, hence faster $[35,36]$. By applying LLLT with diode laser in in vitro studies, it was shown that there was an increase in cell proliferation, increased adhesion of primary fibroblast cultures and osteoblasts on titanium surfaces, as well as an increase in cell proliferation and differentiation of tumor osteoblasts series (osteoblast like cells), and TGF-b and osteocalcin production by cells of tumor lines [76].

The favorable effect of LLLT in osseointegration has been indirectly supported by a study on experimental animals (rabbits) that received implants with reduced initial stability [79]. The same experimental model LLLT, again with a diode laser $(780 \mathrm{~nm})$, resulted in statistically significantly greater bone-implant contact, when ceramic implants were used, as well as increased bone micro-hardness [80].

Furthermore, in cultures of osteoblasts on titanium surface, which received low-power laser radiation, a decrease of the cell population was firstly observed, which soon reversed, while there was an increase of the alkaline phosphatase expression of osteocalcin and BMP-7 [81].

Almost all studies on the effect of laser radiation in osseointegration, relate to the bio-stimulatory action of laser diodes. The review of the literature on the effects of LLLT on cells of the bone tissue, with wavelengths in the infrared spectrum, leads to the conclusion that LLLT promotes cell proliferation of osteoblasts, increases collagen deposition, and creates new bone. It is also emphasized that the application of LLLT was proposed to be applied at the very early stages of healing, because then the cell proliferation potential is still high [82].

\section{References}

1. Anders JJ, Wu X (2016) Comparison of Light penetration of continuous wave $810 \mathrm{~nm}$ and superpulsed $904 \mathrm{~nm}$ wavelength light in anesthetized rats. Photomed Laser Surg 34: 418-424.

2. de Oliveira RF, de Andrade Salgado DMR, Trevelin LT, Lopes RM, Barros da Cunha SR, et al. (2015) Benefits of laser phototherapy on nerve repair. Lasers Med Sci 30: 1395-1406.

3. Rojas JC, Gonzalez-Lima F (2011) Low-level light therapy of the eye and brain. Eye Brain 3: 49-67.

4. Forootan KS, Forghani SF, Seyed PM, Estahbanati HK, Seyed Forootan NS, et al. (2015) Laser therapy after repair of the distal half of the median nerve; a comparative study. Trauma Mon 20: e23816.

5. Zilov VG, Khadartsev AA, Bitsoev VD (2014) Effects of polychromatic visible and infrared light on biological liquid media. Bull Exp Biol Med 157: 470-472. 
6. Hentschke VS, Capalonga L, Rossato DD, Perini JL, Alves JP, et al. (2016) Maximal oxygen uptake and exercise tolerance are improved in rats with heart failure subjected to low-level laser therapy associated with resistance training. Lasers Med Sci 32: 73-85.

7. Tsai SR, Hamblin MR (2017) Biological effects and medical applications of infrared radiation. J Photochem Photobiol B 170: 197-207.

8. de Freitas LF, Hamblin MR (2016) Proposed Mechanisms of Photobiomodulation or Low-Level Light Therapy. IEEE J Sel Top Quantum Electron 22: 348-364.

9. Brown GC (2001) Regulation of mitochondrial respiration by nitric oxide inhibition of cytochrome c oxidase. Biochim Biophys Acta 1504: 46-57.

10. Huang YY, Aaron C, Chen H, Carroll JD, Hamblin MR, et al. (2009) Biphasic dose response in low level light therapy. Dose Response 7: 358-383.

11. Borzabadi-Farahani A (2016) Effect of low-level laser irradiation on proliferation of human dental mesenchymal stem cells; a systemic review. J Photochem Photobiol B 162: 577-582.

12. Quirk BJ, Sannagowdara K, Buchmann EV, Jensen ES, Gregg DC, et al. (2016) Effect of near-infrared light on in vitro cellular ATP production of osteoblasts and fibroblasts and on fracture healing with intramedullary fixation. J Clin Orthop Trauma 7: 234-241.

13. Shiva S, Gladwin MT (2009) Shining a light on tissue NO stores: near infrared release of NO from nitrite and nitrosylated hemes. J Mol Cell Cardiol 46: 1-3.

14. Eslami H, Motahari P, Safari E, Seyyedi M (2017) Evaluation effect of low level Helium-Neon laser and Iranian propolis extract on Collagen Type I gene expression by human gingival fibroblasts: an in vitro study. Laser Ther 26: 105-112.

15. Pal G, Dutta A, Mitra K, Grace MS, Romanczyk TB, et al. (2008) Effect of low intensity laser interaction with human skin fibroblast cells using fiber-optic nano-probes. J Photochem Photobiol B 90: 207.

16. Sommer AP, Mester AR, Trelles MA (2015) Tuning the mitochondrial rotary motor with light. Ann Transl Med 3: 346.

17. Lanzafame RJ, Stadler I, Kurtz AF, Connelly R, Timothy A, et al. (2007) Reciprocity of exposure time and irradiance on energy density during photoradiation on wound healing in a murine pressure ulcer model. Lasers Surg Med 39: 534-542.

18. AlGhamdi KM, Kumar A, Moussa NA (2012) Low-level laser therapy: a useful technique for enhancing the proliferation of various cultured cells. Lasers Med Sci 27: 237-249.

19. Bromm B, Treede RD (1984) Nerve fibre discharges, cerebral potentials and sensations induced by $\mathrm{CO}^{2}$ laser stimulation. Hum Neurobiol 3 : $33-40$.

20. Magerl W, Ali Z, Ellrich J, Meyer RA, Treede RD, et al. (1999) C- and A delta-fiber components of heat-evoked cerebral potentials in healthy human subjects. Pain 82: 127-137.

21. Sato K, Akaike T, Suga M, Ando M, Maeda H, et al. (1994) Generation of free radicals from neocarzinostatin mediated by NADPH/cytochrome P-450 reductase via activation of enediyne chromophore. Biochem Biophys Res Commun 205: 1716-1723.

22. Haslerud S, Magnussen LH, Joensen J, Brandao Lopes-Martins RA, Bjordal JM, et al. (2014) The efficacy of low-level laser therapy for shoulder tendinopathy: a systematic review and meta-analysis of randomized controlled trials. Physiother Res Int 20: 108-125.

23. Jang H, Lee $\mathrm{H}$ (2012) Meta-analysis of pain relief effects by laser irradiation on joint areas. Photomed Laser Surg 30: 405-417.

24. Xiaoting L, Yin T, Yangxi C (2010) Interventions for pain during fixed orthodontic appliance therapy. A systematic review. Angle Orthod 80: 925-932.

25. Gerschman JA, Ruben J, Gebart-Eaglemont J (1994) Low level laser therapy for dentinal tooth hypersensitivity. Aust Dent J 39: 353-357.

26. Wakabayashi H, Hamba M, Matsumoto K, Tachibana H (1993) Effect of irradiation by semiconductor laser on responses evoked in trigeminal caudal neurons by tooth pulp stimulation. Lasers Surg Med 13: 605-610.
27. Chow RT, Heller GZ, Barnsley L (2006) The effect of $300 \mathrm{~mW}, 830 \mathrm{~nm}$ laser on chronic neck pain: a double-blind, randomized, placebocontrolled study. Pain 124: 201-210.

28. Hawkins DH, Abrahamse H (2006) The role of laser fluence in cell viability, proliferation, and membrane integrity of wounded human skin fibroblasts following helium-neon laser irradiation. Lasers Surg Med 38: 74-83.

29. Marques MM, Pereira AN, Fujihara NA, Nogueira FN, Eduardo CP (2004) Effect of low-power laser irradiation on protein synthesis and ultrastructure of human gingival fibroblasts. Lasers Surg Med 34: 260-265.

30. Pejcic A, Kojovic D, Kesic L, Obradovic R (2010) The effects of low level laser irradiation on gingival inflammation. Photomed Laser Surg 28: 69-74.

31. Clark RA, Tonnesen MG, Gailit J, Cheresh DA (1996) Transient functional expression of alphaVbeta 3 on vascular cells during wound repair. Am J Pathol 148: 1407-1421.

32. Larsson L, Decker AM, Nibali L, Pilipchuk SP, Berglundh T, et al. (2015) Regenerative Medicine for Periodontal and Peri-implant Diseases. J Dent Res 95: 255-266.

33. Carney SA, Lawrence JC, Ricketts CR (1967) The effect of light from a ruby laser on the metabolism of skin in tissue culture. Biochim Biophys Acta 148: 525-530.

34. Mester E, Szende B, Gartner P (1968) The effect of laser beams on the growth of hair in mice. Radiobiol Radiother (Berl) 9: 621-626.

35. Bouvet-Gerbettaz S, Merigo E, Jean-Paul R, Carle GF, Rochet N (2009) Effects of low-level laser therapy on proliferation and differentiation of murine bone marrow cells into osteoblasts and osteoclasts. Lasers Surg Med 41: 291-297.

36. Tang E, Arany P (2013) Photobiomodulation and implants: implications for dentistry. J Periodontal Implant Sci 43: 262-268.

37. Mikami S, Oya M, Shimoda M, Mizuno R, Ishida M, et al. (2008) Expression of heparanase in renal cell carcinomas: implications for tumor invasion and prognosis. Clin Cancer Res 14: 6055-6061.

38. Walsh LJ (1997) The current status of low level laser therapy in dentistry. Part 1. Soft tissue applications. Aust Dent J 42: 247-254.

39. Saygun I, Karacay S, Serdar M, Ural AU, Sencimen M, et al. (2007) Effects of laser irradiation on the release of basic fibroblast growth factor (bFGF), insulin like growth factor-1 (IGF-1), and receptor of IGF-1 (IGFBP3) from gingival fibroblasts. Lasers Med Sci 23: 211-215.

40. Hou JF, Zhang H, Yuan X, Li J, Wei YJ, et al. (2008) In vitro effects of lowlevel laser irradiation for bone marrow mesenchymal stem cells: proliferation, growth factors secretion and myogenic differentiation. Lasers Surg Med 40: 726-733.

41. Poon VK, Huang L, Burd A (2005) Biostimulation of dermal fibroblast by sublethal Q-switched Nd:YAG $532 \mathrm{~nm}$ laser: collagen remodeling and pigmentation. J Photochem Photobiol B 81: 1-8.

42. Pourzarandian A, Watanabe H, Ruwanpura MPMS, Aoki A, Ishikawa I (2005) Effect of low-level Er:YAG laser irradiation on cultured human gingival fibroblasts. J Periodontol 76: 187-193.

43. Pourzarandian A, Watanabe H, Ruwanpura SMPM, Aoki A, Noguchi K, et al. (2005) Er:YAG laser irradiation increases prostaglandin E production via the induction of cyclooxygenase-2 mRNA in human gingival fibroblasts. J Periodontal Res 40: 182-186.

44. Feist IS, Giorgio De M, Carneiro SRS, Eduardo CP, Miyagi SPH, et al. (2003) Adhesion and growth of cultured human gingival fibroblasts on periodontally involved root surfaces treated by Er:YAG laser. J Periodontol 74: 1368-1375.

45. Medrado AR, Pugliese LS, Reis SRA, Andrade ZA (2003) Influence of low level laser therapy on wound healing and its biological action upon myofibroblasts. Lasers Surg Med 32: 239-244.

46. Chen YJ, Jeng JH, Jane Yao CC, Chen MH, Hou LT, et al. (2005) Longterm effect of pulsed Nd:YAG laser irradiation on cultured human periodontal fibroblasts. Lasers Surg Med 36: 225-233. 
47. Chen YJ, Jeng JH, Lee BS, Chang HF, Chen KC, et al. (2000) Effects of Nd:YAG laser irradiation on cultured human gingival fibroblasts. Lasers Surg Med 27: 471-478.

48. Basford JR (1986) Low-energy laser treatment of pain and wounds: hype, hope, or hokum? Mayo Clin Proc 61: 671-675.

49. Lundeberg T, Malm M (1991) Low-power HeNe laser treatment of venous leg ulcers. Ann Plast Surg 27: 537-539.

50. Vitse J, Bekara F, Byun S, Herlin C, Teot L (2017) A double-blind, placebo-controlled randomized evaluation of the effect of low-level laser therapy on venous leg ulcers. Int J Low Extrem Wounds 16: 29-35.

51. Brosseau L, Welch V, Wells G, deBie R, Gam A, et al. (2005) Low level laser therapy (Classes I, II and III) for treating rheumatoid arthritis. Cochrane Database Syst Rev (4): CD002049.

52. Aimbire F, Albertini R, Pacheco MTT, Castro-Faria-Neto HC, Leonardo PSLM, et al. (2006) Low-level laser therapy induces dose-dependent reduction of TNFalpha levels in acute inflammation. Photomed Laser Surg 24: 33-37.

53. Lucas C, Criens-Poublon LJ, Cockrell CT, de Haan RJ (2002) Wound healing in cell studies and animal model experiments by Low Level Laser Therapy; were clinical studies justified? a systematic review. Lasers Med Sci 17: 110-134.

54. Woodruff LD, Bounkeo JM, Brannon WM, Dawes KS, Barham CD, et al. (2004) The efficacy of laser therapy in wound repair: a meta-analysis of the literature. Photomed Laser Surg 22: 241-247.

55. Peplow PV, Chung TY, Baxter GD (2010) Laser photobiomodulation of proliferation of cells in culture: a review of human and animal studies. Photomed Laser Surg 28: S3-S40.

56. Bisht D, Gupta SC, Misra V, Mital VP, Sharma P (1994) Effect of low intensity laser radiation on healing of open skin wounds in rats. Indian J Med Res 100: 43-46.

57. Neiburger EJ (1995) The effect of low-power lasers on intraoral wound healing. N Y State Dent J 61: 40-43.

58. Kitsmaniuk ZD, Demochko Vb, Popovich VI (1992) The use of lowenergy lasers for preventing and treating postoperative and radiationinduced complications in patients with head and neck tumors. Vopr Onkol 38: 980-986.

59. Posten W, Wrone DA, Dover JS, Arndt KA, Silapunt S, et al. (2005) Lowlevel laser therapy for wound healing: mechanism and efficacy. Dermatol Surg 31: 334-340.

60. Gkogkos AS, Karoussis IK, Prevezanos ID, Marcopoulou KE, Kyriakidou K, et al. (2015) Effect of Nd:YAG Low Level Laser Therapy on Human Gingival Fibroblasts. Int J Dent 2015: 1-7.

61. Soares DM, Ginani F, Henriques AG, Barboza CAG (2013) Effects of laser therapy on the proliferation of human periodontal ligament stem cells. Lasers Med Sci 30: 1171-1174.

62. Aleksic V, Aoki A, Iwasaki K, Takasaki AA, Wang CY, et al. (2010) Lowlevel Er:YAG laser irradiation enhances osteoblast proliferation through activation of MAPK/ERK. Lasers Med Sci 25: 559-569.

63. Hamblin MR (2017) Mechanisms and applications of the antiinflammatory effects of photobiomodulation. AIMS Biophys 4: 337-361.

64. Nomura K, Yamaguchi M, Abiko Y (2001) Inhibition of interleukin-1beta production and gene expression in human gingival fibroblasts by lowenergy laser irradiation. Lasers Med Sci 16: 218-223.

65. Chellini F, Sassoli C, Nosi D, Deledda C, Tonelli P, et al. (2010) Low pulse energy Nd:YAG laser irradiation exerts a biostimulative effect on different cells of the oral microenvironment: "an in vitro study". Lasers Surg Med 42: 527-539.

66. Weng Y, Dang Y, Ye X, Liu N, Zhang Z, et al. (2011) Investigation of irradiation by different nonablative lasers on primary cultured skin fibroblasts. Clin Exp Dermatol 36: 655-660

67. Hakki SS, Bozkurt SB (2011) Effects of different setting of diode laser on the mRNA expression of growth factors and type I collagen of human gingival fibroblasts. Lasers Med Sci 27: 325-331.

68. Mayahara K, Yamaguchi A, Sakaguchi M, Igarashi Y, Shimizu N (2010) Effect of Ga-Al-As laser irradiation on COX-2 and cPLA2-alpha expression in compressed human periodontal ligament cells. Lasers Surg Med 42: 489-493.

69. Hayashi H, Terao A, Kunimatsu R, Kawata T (2014) Effects of a low level laser on periodontal tissue in hypofunctional teeth. PLoS One 9: e100066.

70. Kreisler M, Meyer C, Stender E, Daubländer M, Zönnchen BW, et al. (2001) Effect of diode laser irradiation on the attachment rate of periodontal ligament cells: an in vitro study. J Periodontol 72: 1312-1317.

71. Maia LG, Alves AV, Bastos TS, Moromizato LS, Verde IBL, et al. (2014) Histological analysis of the periodontal ligament and alveolar bone during dental movement in diabetic rats subjected to low-level laser therapy. J Photochem Photobiol B 135: 65-74.

72. Ozcelik O, Haytac MC, Kunin A, Seydaoglu G (2008) Improved wound healing by low-level laser irradiation after gingivectomy operations: a controlled clinical pilot study. J Clin Periodontol 35: 250-254.

73. Arisu HD, Turkoz E, Bala O (2006) Effects of Nd:Yag laser irradiation on osteoblast cell cultures. Lasers Med Sci 21: 175-180.

74. Altan BA, Sokucu O, Ozkut MM, Inan S (2010) Metrical and histological investigation of the effects of low-level laser therapy on orthodontic tooth movement. Lasers Med Sci 27: 131-140.

75. Pyo SJ, Song WW, Kim IR, Park BS, Kim CH, et al. (2012) Low-level laser therapy induces the expressions of BMP-2, osteocalcin, and TGF-beta1 in hypoxic-cultured human osteoblasts. Lasers Med Sci 28: 543-550.

76. Khadra M, Lyngstadaas SP, Haanæs HR, Mustafa K (2005) Effect of laser therapy on attachment, proliferation and differentiation of human osteoblast-like cells cultured on titanium implant material. Biomaterials 26: 3503-3509.

77. AboElsaad NS, Soory M, Gadalla LMA, Ragab LI, Dunne S, et al. (2008) Effect of soft laser and bioactive glass on bone regeneration in the treatment of infra-bony defects (a clinical study). Lasers Med Sci 24: 387-395.

78. Ozawa Y, Shimizu N, Kariya G, Abiko Y (1998) Low-energy laser irradiation stimulates bone nodule formation at early stages of cell culture in rat calvarial cells. Bone 22: 347-354.

79. Campanha BP, Gallina C, Geremia T, Drumond Loro RC, Valiati R, et al. (2010) Low-level laser therapy for implants without initial stability. Photomed Laser Surg 28: 365-369.

80. Guzzardella GA, Torricelli P, Aldini NN, Giardino R (2003) Osseointegration of endosseous ceramic implants after postoperative lowpower laser stimulation: an in vivo comparative study. Clin Oral Implants Res 14: 226-232.

81. Petri AD, Teixeira LN, Crippa GE, Beloti MM, de Oliveira PT, et al. (2010) Effects of low-level laser therapy on human osteoblastic cells grown on titanium. Braz Dent J 21: 491-498.

82. Pinheiro AL, Gerbi ME (2006) Photoengineering of bone repair processes. Photomed Laser Surg 24: 169-178. 